\title{
Party Funding: Back to square one (and a half) or every cloud has a silver lining?
}

\author{
Justin Fisher (Brunel University)
}

\section{Introduction}

On $30^{\text {th }}$ October 2007, Sir Hayden Phillips announced that the inter-party talks on party funding, which had been established following his report in March of the same year, had been suspended. At the time, it appeared that barring another party funding 'episode', the attempt to broker consensus on broad reform in party funding had failed. In effect, it meant that we were effectively back to the position that had existed prior to the 'loans for peerages' episode in 2006 on the vexed question of party funding reform. True, there had been some change (initiated by the government in the immediate wake of the 'loans for peerages' stories) and in the Queen's speech at the commencement of the current session, there was an indication that legislation in this field may be pursued. But the shape of proposals was unclear, and any reforms were unlikely to be as comprehensive as those proposed by the Phillips report. However, in late November 2007, it emerged that Labour had been receipt of over $£ 600,000$ in donations via intermediaries. If this were proven, it would be a clear breach of the Political Parties, Elections \& Referendums Act 2000 (PPERA). The initial consequence was the swift resignation of Labour's General Secretary and within days, the Electoral Commission had passed the matter over to the Police. At the time of writing (early December 2007), the outcome of that investigation is not known, but in the light of this episode, the Prime Minister has indicated that further reforms in party funding will take place. If reforms do go through, the unfortunate cloud of November 2007 may have a silver lining for those seeking reform. If the government fails to introduce reform, we will effectively be back to square one.

\section{Phillips Review}

Reviewing the funding of political parties in Britain is not a new pursuit. As the Phillips report (p.1) notes: 'For the last 20 years there has been an intermittent but persistent debate about how to reform the funding of party politics.' Indeed, that timeframe might well be extended back to the mid-1970s with the publication of the Houghton Report and the introduction of 'Short' money for opposition parties' work in parliament. Notwithstanding, 
the Phillips review was the latest 'root and branch' examination of a political problem that steadfastly refuses to be solved.

The review was established following the events of Spring 2006. It emerged that Labour had also sought loans rather than donations, and that a number of those making them had subsequently been nominated for political honours. In fact, all nominations were rejected by the House of Lords appointments committee, but a 'loans for peerages' crisis ensued which led to a lengthy and expensive police investigation, but ultimately no charges.

Although the government acted swiftly to close the loans loophole by tagging a provision onto the Electoral Administration Bill, which came into force in the autumn of 2006, the loans episode threw the whole issue of party funding into focus again-especially with the Conservatives performing a volte face and championing the idea not only of a $£ 50,000$ cap on individual contributions (which the Tories had previously dismissed as an infringement on liberty), but also of more comprehensive state funding (Tyrie, 2006). The upshot was that the Prime Minister asked Sir Hayden Phillips to review the whole basis of party funding.

The review was a lengthy one with much public debate surrounding it. Importantly, there was a great deal of political consensus surrounding the supposed need for reform in certain areas. All parties, for example, were in broad agreement about reducing the sums that could be spent on national campaigns and on extending state provision. However, there was disagreement in two principal areas. First, some in the Labour Party feared that if trade union affiliation payments were capped as was proposed for corporate and individual donations, this would threaten the constitutional link between affiliated unions and Labour. The review therefore proposed that affiliation payments from unions should be regarded instead as being individual contributions from union members for the purposes of the donation limit. This would be permissible if these contributions were made transparently and could be traced back to the individuals concerned. This proposal caused difficulties for Labour for two reasons. First, it challenged the principle of collective contributions by affiliated organisations. Secondly, the emphasis on transparency and traceability could be conceived as a version of 'contracting in' rather than 'contracting out'. The second area of contention surrounded

1 The principle of 'contracting out' or claiming exemption from payment of trade union political funds was established by the Trade Union Act 1913. The Trade Disputes and Trade Unions Act 1927 introduced a system of 'contracting in' or making a positive decision to contribute, rather than a 
proposals to regulate and restrict spending at constituency level for a period of at least one year before the election date. This was opposed by the Conservatives.

The results of the review were published in March 2007 (see Box 1), but with these two issues outstanding. Given that Phillips argued that 'Nothing should be agreed until everything is agreed' (p. 4) Phillips proposed the establishment of all party talks (comprising the Conservatives, Labour and the Liberal Democrats) to try and reach a consensus on the outstanding issues.

\section{Box 1}

\section{Recommendations of the Hayden Phillips Review}

1. The status quo, in which there are no caps on donations, is unsustainable and therefore donations to parties should be limited.

2. Restrictions on donations should be buttressed by measures to prevent breaches of the new regulations.

3. Expenditure on general election campaigns has progressively grown and should now be reduced.

4. Controls on expenditure by all third parties should be strengthened.

5. The price of a fairer, more stable system of party political financing may be some increase in public funding of political parties.

6. Any increase in public funding should be linked to a recognised measure, or measures, of popular support, and should encourage greater democratic engagement.

7. The public should have access to better, clearer information on the sources of party income.

8. A new funding settlement will present the regulator with fresh challenges. The Electoral Commission must have the powers, the capacity and the practical experience needed to fulfil its new role.

\section{All-Party Talks}

Talks began in May 2007 and in August 2007, a draft agreement was put to the parties. In respect of the two thorny issues the following were put forward. For trade unions, it was again proposed that rather than union affiliation payments being regarded as collective contributions, they should instead be seen as individual contributions to the Labour Party by affiliated union members. Thus, a union's affiliation fee would be an aggregation only of the

making a claim to 'contract out'. 'Contracting out' was re-established by the Trade Disputes and Trade Unions Act 1946. 'A return to 'contracting in' was proposed in the Green Paper Democracy in Trade Unions (1983), but was dropped from subsequent legislation in the form of the Trade Union Act 1984. 
amounts paid by individuals into the political fund as their contribution to the affiliation fee. This would be the case if the following information was provided on all affiliated union membership application forms: an explanation of the political fund and the union's affiliation to a political party; an explanation of how much individual members contribute to the political fund and towards the union's affiliation fee; an explanation of the trade union member's right at any time to stop contributing to the political fund and the union's affiliation fee and clear information how to do this; an explanation that is a member ceased to contribute, their membership would be reduced accordingly. Trade union members were to be reminded annually of the amount they were contributing and of how to opt out should they wish to do so. The principle change, here was the removal of the threat of 'contracting in'. However, the challenge to collective affiliation remained, together with a proposal to cap any donations from the political funds of trade unions to a maximum of $£ 50,000$ - in line with other donations.

For party expenditure, the original proposals in the report were clarified such that spending controls would now apply to the whole Westminster electoral cycle. Moreover, the differentiation between 'national' and 'local' spending would effectively disappear. Instead, a single overall limit would apply to each party, including all its constituent organisations. In comparison with what is currently in place, this proposal differed significantly. Firstly, the present system for Westminster elections limits spending at national and at constituency level. At national level, campaign spending is limited to a maximum of $£ 18.4$ million during the period of 365 days before the election. At constituency level, spending (which is candidate, rather than party spending) is only regulated in the period between the dissolution of parliament and polling day. In 2005, this amounted to $£ 11,359$ on average per candidate for seats in Great Britain. These proposals not only suggested the integration of all levels of campaigning outside of the election period, but also covered 'non-campaigning' expenditure (save for a few exceptions). It also proposed maintaining existing restrictions on candidate spending and tightening them to include the costs of direct mail and call centres under the heading of spending within a constituency. Fisher et al $(2005,2007)$ show how this has become a key aspect of national campaigning and has blurred the distinction between national and candidate expenditure.

Whilst the Liberal Democrats were involved in these talks, in truth, the real debates have been between Labour and the Conservatives, and mis-information has been spread by both 
sides. In respect of the trade unions, an influential lobby within the Labour Party suggested that these proposals would threaten the historic relationship between the party and affiliated unions. The reason for this is that constitutionally, trade unions affiliate to Labour on the basis of the number of members they have (or at least the numbers they declare for the purposes of affiliation). Capping contributions, it is argued could make it impossible for unions to have differential affiliation since a cap of say $£ 50 \mathrm{k}$ would be some way below the current affiliation levels of the larger unions. Equally, a move towards 'individualizing' members' payments to Labour would threaten the principle of collective affiliation. Yet these are debateable views. First, a perusal of the extensive literature on Labour and the unions (see for example, Minkin, 1991) stresses the point that the relationship is far more than a financial one - it is a movement built on fraternity. The financial arrangements are simply a byproduct. If that is the case, then it is arguable that a cap and/or changes to the position of individual levy payers would not threaten the heart of the relationship, simply the ability of unions to pay sizeable amounts to Labour. Secondly, there was no suggestion that Labour should divorce itself from the unions. Rather, these proposals could be seen as a way of accommodating Labour's relationship with trade unions whilst seeking to address the apparent problem of large contributions. It would be politically naïve, for example, to argue that large donations from companies and individuals were a problem and could be subject to a cap, whilst claiming that trade union payments were simply the aggregation of members' political fund payments - a case of good cap, bad cap

The Conservatives did not help this situation. Whereas the Phillips report proposed caps, the Conservatives - on the front foot with Labour experiencing political difficulties - turned the matter into a question of Labour's divorce from the unions. Such a move was unnecessary and was bound to make even those in the Labour party who were happy to see reform, more defensive of existing arrangements. On this matter, both sides are culpable for the breakdown in talks - Labour for taking a very partial view of the proposals on caps, the Conservatives for over playing their hand by turning this into a matter of Labour's relationship with the unions rather than one of political equity.

In respect of spending limits, much of this was driven initially by Peter Bradley - a former Labour MP who lost his seat in The Wrekin in 2005. The Conservative victor's local party (like a number of others fighting marginal seats) was the recipient of the so-called 'Ashcroft money', whereby significant sums were contributed, and used for campaigning by 
Conservative challengers in the period before the original campaign at constituency level began. In this, and other seats where the Conservatives were spending heavily, it was argued that elections were being 'bought'. Indeed, recent research lends some support to this thesis (Johnston \& Pattie, 2007). Clearly, if financial prowess was distorting the electoral process, this could be regarded as a problem. Indeed, this is why spending limits at constituency level were originally introduced in 1883.

However, once again, both sides gave rather partial accounts of the problem and both arguably can be blamed for the failure to reach a compromise. Much political activity occurs in constituencies prior to the 'official' campaign - especially in marginal seats (Denver et al, 2003, Fisher et al, 2005, 2006a, 2007). That being so, some change in the rules was sensible. The Conservatives, however, argued that this was not possible because their party workers were essentially amateurs and it would be unreasonable to impose additional burdens upon them. On the face of it, this is not an unreasonable position (see below), but to argue against any extension of the campaign period was an excessive response. The Conservatives also claimed that this spending offset the incumbent advantage of Labour MPs in sending out newsletters to constituents. Apart from ignoring the fact that this privilege is also afforded to Conservative MPs (and those of other parties), it ignored the fact that MPs communicate with constituents for a good reason - they are representing them. MPs are allocated a 'Communications Allowance' in order to promote understanding by constituents of MPs actions. Moreover, it is stipulated that expenditure from these allowances must be used only for the conduct of Parliamentary duties, and not for political party purposes, including electioneering.

Labour's claims on this matter are also open to question. Research on local party campaigning shows clearly, for example, how preparation for election has been increasing in marginal seats by all parties (see, for example, Fisher et al 2006a). Secondly, early preparation does not only take a monetary form. Labour has previously indulged in preelection campaigning on a fairly significant scale. Prior to the 2001 election, for example, Labour MPs in marginal seats were strongly encouraged to spend less time in Parliament and more time in their constituencies - a successful tactic (Johnston et al, 2002). Moreover, Fisher (1999) shows that party spending should not necessarily be seen as a constant sum money may be spent well as well as poorly. And, recent research suggests that voters respond better to traditional, volunteer-led campaigning, rather than modern, financially intensive 
techniques (Fisher \& Denver, 2007). In sum, Labour effectively exaggerated the problem presumably in response to Conservative attacks on the union issue. However, all this could have been avoided through a reasonable compromise. In 2006, the Electoral Commission proposed extending the election period at constituency level to four months - or to be precise, January $1^{\text {st }}$ in any election year ${ }^{2}$. This provision was to be tagged onto the Electoral Administration Act, but both parties rejected it. Thus, the Conservatives' objections to yearlong or even continuous regulation of constituency spending were reasonable, but to four months, were not.

\section{Where now?}

Where does this leave us? The revelations that Labour seemingly knowingly accepted donations through intermediaries led to Gordon Brown announcing that the government would press forward with reform, and indicated that regulation of trade union contributions might now be included. The Conservatives were caught out a little by this and indicated that Labour should consider its entire relationship with the unions. All concerned should, however, proceed with a little caution. The Phillips Review was thorough and critically considered the issues collectively - caps or further state funding, for example, should not be considered in isolation. By way of contrast, knee-jerk reforms, and those driven by partisan interest are the worst kind and are most likely to fail, or be subject to partisan revision. Thus, the Conservatives should resist the temptation to overplay their hand and insist on a Labourtrade union divorce. Buoyed no doubt by Labour's political problems since the Autumn and the party being subject to a police investigation, it is tempting to do so. But it would be a mistake. The Conservatives' original position of a cap was reasonable and principled - they would 'suffer' as much as other parties (though, this suffering for all parties would be tempered by increases in state aid). The desire to jeopardise the entire relationship between Labour and the unions is not reasonable. It appears nakedly partisan, and as Mrs Thatcher's government discovered when passing the Trade Union Act of 1984, it can backfire (Fisher, 1992). Put bluntly, Labour opposition will become more entrenched if party funding rules are seen to overstep the mark from the principle of equity to a 'one size fits all' approach to party organisation.

2 The date of January $1^{\text {st }}$ was selected on the grounds that elections are likely to be held in the first week in May, as was the case in 1997 and 2005, and was originally intended to be the case in 2001. 
Equally, Labour should resist to temptation to attempt to seek partisan advantage by overregulating constituency spending in an attempt to protect its marginal seats in the next general election. Moreover, their proposals will harm their own volunteers just as much, if not more, than their opponents. Put bluntly, who would want to be a volunteer agent legally responsible for campaigns for a whole year, if not more? For all parties, the number of permanent (either full or part-time) agents has declined, but the Conservatives still have more. Fisher et al (2006b) show that by 2001 , some $37 \%$ of Conservative constituencies had permanent agents whilst the figure for Labour was just 5\%. Even if we count 'special organisers', some $89 \%$ of Labour's constituencies had voluntary agents. Labour's proposals therefore will be a huge disincentive to be involved in local campaigns and will surely lead to many cases of unintended law-breaking.

\section{Conclusions}

The 'problem' of political finance refuses to go away. While the Political Parties, Elections \& Referendums Act addressed many to the historic problems, some issues remain, notably concerns with large donations and the inability of to fund their activities adequately. The Phillips review was at attempt to deal with these ongoing problems, but at the time of writing, has been defeated by intransigence and a desire to preserve partisan advantage. If nothing changes, we will be back to square one as of the situation following the introduction of PPERA. Or to be more accurate, back to square one and a half, since the 'loans for peerages' episode did at least lead to loans being put on an identical legal footing to donations. However, the revelations of November 2007 may well have put party funding reform back on the agenda. Ironically, this is a result of the existing regulations working well. Transparency led to the discovery of apparent wrong-doing and the referral of the matter to the Police following appropriate investigations by the Electoral Commission. The key will be how far the government is prepared to press for reform legislation during the remainder of its current term of office. Ideally, reforms will be generated through consensus as they were with PPERA. If there is serious conflict, however, the government risks either running out of time or passing legislation that could be subject to rapid revision should the Conservatives win the next election. The rational and principled response therefore should be to seek consensus. 


\section{References}

Denver, D., Hands, G., Fisher, J. and MacAllister, I. (2003) 'Constituency Campaigning in Britain 1992-2001: Centralisation and Modernisation', Party Politics 9 (5), 541-59.

Fisher, J. (1992) 'Trade Union Political Funds \& the Labour Party', in P. Norris, I. Crewe, D. Denver \& D. Broughton (eds) British Elections \& Parties Yearbook 1992 Hemel Hempstead: Harvester Wheatsheaf, pp.111-23

Fisher, J. (1999) 'Party expenditure and electoral prospects: a national level analysis of Britain', Electoral Studies 18: 519-32.

Fisher, J. Denver, D. and Hands, G. (2006a) 'The Relative Electoral Impact of Central Party Co-ordination and Size of Party Membership at Constituency Level', Electoral Studies 25(4), 664-76.

Fisher, J. Denver, D. and Hands, G. (2006b) 'Unsung Heroes? Constituency Election Agents in British General Elections', British Journal of Politics \& International Relations Vol. 8 (4), 569-86.

Fisher, J. and Denver, D. (2007) 'From Foot Slogging to Call Centres: Traditional and Modern Modes of Constituency Campaigning 1992-2005'. Paper presented at Britain After Blair: The Legacy and the Future. Conference organised by the British Politics Group of the American Political Science Association, Chicago.

Fisher, J., Fieldhouse, E., Denver, D., Russell, A. \& Cutts, D. (2005) The General Election 2005: Campaign Analysis. Report produced for the Electoral Commission.

Fisher, J., Denver, D., Fieldhouse, E., Russell, A. \& Cutts, D. (2007) 'Constituency Campaigning in 2005: Ever More Centralisation?' in D. Wring \& J. Green (eds) Political Communications: The British General Election of 2005 Basingstoke: Palgrave, pp.79-92.

Johnston, R., Cowley, P., Pattie, C. and Stuart, M. (2002) 'Voting in the House or Wooing the Voters at Home: Labour MPs and the 2001 General Election Campaign', Journal of Legislative Studies, 8 (2), 9-22.

Johnston, R. and Pattie, C. (2007) 'Funding Local Political Parties in England and Wales: Donations and Constituency Campaigns' British Journal of Politics \& International Relations, 9 (3), 365-95.

Minkin, L. (1991) The Contentious Alliance: Trade Unions and the Labour Party. Edinburgh: Edinburgh University Press. 
Phillips, H.(2007) Strengthening Democracy: Fair and Sustainable Funding of Political Parties. The Review of the Funding of Political Parties. London: HMSO.

Tyrie, A. (2006) Clean Politics. London: Conservative Party. 